\title{
Experimental drought and heat can delay phenological development and reduce growth in semiarid trees.
}

\begin{tabular}{|c|c|}
\hline Journal: & Global Change Biology \\
\hline Manuscript ID: & Draft \\
\hline Wiley - Manuscript type: & Primary Research Articles \\
\hline Date Submitted by the Author: & $\mathrm{n} / \mathrm{a}$ \\
\hline Complete List of Authors: & $\begin{array}{l}\text { Adams, Henry; Los Alamos National Laboratory, Earth and Environmental } \\
\text { Sciences Division } \\
\text { Collins, Adam; Los Alamos National Laboratory, Earth and Environmental } \\
\text { Sciences Division } \\
\text { Briggs, Samuel; Los Alamos National Laboratory, Earth and Environmental } \\
\text { Sciences Division } \\
\text { Vennetier, Michel; Irstea, UR Ecosystèmes Méditerranéens et Risques } \\
\text { Dickman, L.; Los Alamos National Laboratory, Earth and Environmental } \\
\text { Sciences Division } \\
\text { Sevanto, Sanna; Los Alamos National Laboratory, Earth and Environmental } \\
\text { Sciences Division } \\
\text { Garcia-Forner, Nuria; Universitat Autònoma de Barcelona, } \\
\text { McDowell, Nate; Los Alamos National Laboratory, Earth and Environmental } \\
\text { Sciences Division }\end{array}$ \\
\hline Keywords: & $\begin{array}{l}\text { phenology, climate change, Juniperus monosperma, Juniper, Pinus edulis, } \\
\text { piñon pine, non-structural carbohydrate, water potential }\end{array}$ \\
\hline Abstract: & $\begin{array}{l}\text { Higher temperatures associated with climate change are anticipated to } \\
\text { trigger an earlier start to the growing season, which could increase the } \\
\text { terrestrial C sink strength. Yet greater variability in the amount and timing } \\
\text { of precipitation are also expected with higher temperatures, bringing } \\
\text { increased drought stress to many ecosystems. We experimentally } \\
\text { assessed the effects of higher temperature and drought on the foliar } \\
\text { phenology and growth of mature trees of two semi-arid conifer } \\
\text { species. We exposed field-grown trees to a } \sim 45 \% \text { reduction in } \\
\text { precipitation with a rain-out structure, a } 4.8^{\circ} \mathrm{C} \text { temperature increase with } \\
\text { open-top chambers, and a combination of both simultaneously } \\
\text { (heat+drought). Over the } 2013 \text { growing season, heat, drought, and } \\
\text { heat+drought treatments reduced shoot and needle growth in piñon pine } \\
\text { (Pinus edulis) by } \geq 39 \%, \text { while juniper (Juniperus monosperma) had low } \\
\text { growth and little response to these treatments. Needle emergence on } \\
\text { primary axis branches of piñon pine was delayed in heat, drought, and } \\
\text { heat+drought treatments by } 19 \text { to } 57 \text { days, while secondary axis branches } \\
\text { were less likely to produce needles in the heat treatment, and produced no } \\
\text { needles at all in the heat+drought treatment. Growth of shoots and } \\
\text { needles, and the timing of needle emergence correlated inversely with } \\
\text { xylem water tension and positively with non-structural carbohydrate }\end{array}$ \\
\hline
\end{tabular}


concentrations. Our findings demonstrate the potential for delayed phenological development and reduced growth with higher temperatures and drought in tree species that are vulnerable to drought and reveal potential mechanistic links to physiological stress responses. Climate change projections of an earlier and longer growing season with higher temperatures, and consequent increases in terrestrial $C$ sink strength, may be incorrect for regions where plants will face increased drought stress with climate change.

SCHOLARONE ${ }^{m}$

Manuscripts

This is the accepted version of the following article: Adams, Henry D., et al. "Experimental drought and heat can delay phenological development and reduce foliar and shoot growth in semiarid trees" in Globlal change biology, vol. 21, Issue 11 (Nov. 2015), p. 4210-4220, which has been published in final form at DOI 10.1111/gcb.13030. This article may be used for non-commercial purposes in accordance with Wiley Terms and Conditions for Self-Archiving. 
1 Experimental drought and heat can delay phenological development and reduce growth in

2 semiarid trees.

4 Running Head: Drought and heat affect phenology and growth

5

6 Henry D. Adams ${ }^{1 *}$, Adam D. Collins ${ }^{1}$, Samuel P. Briggs ${ }^{1}$, Michel Vennetier $^{2}$, L. Turin

7 Dickman ${ }^{1}$, Sanna A. Sevanto ${ }^{1}$, Núria Garcia-Forner ${ }^{3,4}$, Nate G. McDowell ${ }^{1}$.

8

$9 \quad{ }^{1}$ Earth and Environmental Sciences, Los Alamos National Laboratory, Los Alamos, NM USA

$10 \quad{ }^{2}$ Irstea, UR Ecosystèmes Méditerranéens et Risques, Aix-en-Provence, France

$11{ }^{3}$ Centre de Recerca Ecològica i Aplicacions Forestals (CREAF), Cerdanyola del Vallès, Spain

12 Universitat Autònoma de Barcelona, Cerdanyola del Vallès, Spain

13

14 *Corresponding Author: phone: (+1) 505665 7661, fax: (+1) 505665 3866,

15 adamshenryd@gmail.com

16

17 Keywords: phenology, climate change, Juniperus monosperma, Juniper, Pinus edulis, piñon

18 pine, non-structural carbohydrate, water potential, drought experiment.

19

20 Primary Research Article 


\section{Abstract.}

Higher temperatures associated with climate change are anticipated to trigger an earlier

24 start to the growing season, which could increase the terrestrial C sink strength. Yet greater

25 variability in the amount and timing of precipitation are also expected with higher temperatures,

26 bringing increased drought stress to many ecosystems. We experimentally assessed the effects

27 of higher temperature and drought on the foliar phenology and growth of mature trees of two

28 semi-arid conifer species. We exposed field-grown trees to a $\sim 45 \%$ reduction in precipitation

29 with a rain-out structure, a $4.8^{\circ} \mathrm{C}$ temperature increase with open-top chambers, and a

30 combination of both simultaneously (heat+drought). Over the 2013 growing season, heat,

31 drought, and heat + drought treatments reduced shoot and needle growth in piñon pine (Pinus

32 edulis) by $\geq 39 \%$, while juniper (Juniperus monosperma) had low growth and little response to

33 these treatments. Needle emergence on primary axis branches of piñon pine was delayed in heat,

34 drought, and heat+drought treatments by 19 to 57 days, while secondary axis branches were less

35 likely to produce needles in the heat treatment, and produced no needles at all in the

36 heat + drought treatment. Growth of shoots and needles, and the timing of needle emergence

37 correlated inversely with xylem water tension and positively with non-structural carbohydrate

38 concentrations. Our findings demonstrate the potential for delayed phenological development

39 and reduced growth with higher temperatures and drought in tree species that are vulnerable to

40 drought and reveal potential mechanistic links to physiological stress responses. Climate change

41 projections of an earlier and longer growing season with higher temperatures, and consequent

42 increases in terrestrial $\mathrm{C}$ sink strength, may be incorrect for regions where plants will face

43 increased drought stress with climate change. 
47

\section{Introduction.}

The phenology of plants, i.e. the timing of development and growth, has a strong influence on the atmospheric concentration of $\mathrm{CO}_{2}$ at both short and long time scales. Interannual fluctuations of atmospheric $\mathrm{CO}_{2}$ concentrations illustrate the dominance of terrestrial phenology on earth's atmosphere (Keeling 1960, Keeling et al. 1996). At longer-time scales changes in the phenology of the terrestrial biosphere could affect planetary climate regulation, as changes in growing season length and associated increases in terrestrial primary production are an important feedback to climate change (Richardson et al. 2010, 2012, 2013, Keenan et al. 2014). The potential effects of climate change on growing season shifts, typically estimated as a negative feedback on warming, are represented in the global vegetation components of earth system models used in climate change projection (Richardson et al. 2012, Oleoson et al. 2013, Keenan et al. 2014).

Studies of long-term records have consistently found that increased temperatures are linked to an earlier and longer growing season in temperate (Aono and Kazui 2008, MillerRushing and Primack 2008, Primack et al. 2009) and Mediterranean ecosystems (Peñuelas et al 2002, Ogaya and Peñuelas 2004, Gordo and Sanz 2009). Warming experiments have often shown the same effect of earlier growth and an extended growing season in trees (Norby et al. 2003, Morin et al. 2010, Han et al. 2014). There is also evidence from experiments that increased temperatures do not always produce the typical response but can have no effect on phenological timing (Guak et al. 1998, Kuster et al. 2014). A potential explanation for such atypical responses could be that temperature increases can be associated with an increase in drought stress (Overpeck and Udall 2010, Williams et al. 2013). Observations of reduced

67 growth, decreased branching rate, and delayed leaf development have been reported in trees 
68 subjected to rainfall exclusion experiments (Borghetti et al. 1998, Ogaya and Peñuelas 2004,

69 Peñuelas et al. 2004, Girard et al. 2011, 2012, Limousin et al. 2012).

Investigation of the physiological causes of phenological responses may be a useful

71 approach for improving climate change predictions, given the variation in temperature and

72 drought effects on tree growth and development, (Schaber and Badeck 2003). Growth and

73 development are highly sensitive to stress from water availability (Körner 2003, Fatichi et al.

74 2014). Following the sink limitation hypothesis, reduced growth from drought is thought to be

75 caused by the direct effects on turgor necessary for cell wall expansion at active meristems, not

76 through any source limitation of $\mathrm{C}$ assimilation or availability of stored $\mathrm{C}$ resources (Körner

77 2003, Würth et al. 2005, Fatichi et al. 2014, Palacio et al. 2014). This hypothesis is supported by

78 much work demonstrating that drought, reflected in high xylem water tensions, limits growth

79 more than photosynthesis, and that non-structural carbohydrates (NSC) tend to increase in

80 response to stress and are reduced when environmental conditions favor growth, consistent with

81 change in C sink demand (Tissue and Wright 1995, Körner 2003, Würth et al. 2005, Oberhuber

82 et al. 2011, Gruber et al. 2012, Deslauriers et al. 2014, Fatichi et al. 2014, Dickman et al. 2015).

83 Changes in carbon supply through reduced photosynthesis serve to exacerbate these impacts

84 (McDowell 2011, Adams et al. 2013, Sevanto et al. 2014, Dickman et al. 2015, Hartmann et al. 85 2015).

Few studies have examined the combined effects of increased temperature and drought

87 on phenological responses in mature trees, despite the need for improved phenology models in

88 global change assessments (Richardson et al. 2012). Even fewer studies have investigated the

89 physiological processes behind the phenological responses to these environmental stresses. In

90 this study, we measured phenological, growth, and physiological responses to an experimental 
91 field manipulation of temperature and drought in mature trees of two semi-arid conifer species,

92 Juniperus monosperma and Pinus edulis. These tree species are widespread across the

93 Southwest USA, a semi-arid region where tree phenological responses to climate have not been

94 well studied. Our objectives were to determine the effect of temperature and drought, separately

95 and in combination, on tree phenology, and to investigate the causal links between physiological

96 and phenological responses to these treatments. We tested the following hypotheses:

97 1. Increased temperature will cause earlier phenological development and increased growth.

98 2. Drought will delay development and reduce growth.

99 3. In combination, the effects of drought will counteract any heat effects, resulting in no 100 change in development and growth relative to ambient conditions.

101 4. Growth and development will be constrained primarily by xylem tension and will be 102 either unrelated or negatively correlated with NSC concentration.

103

104 Methods.

105 Site description and experimental design.

106 The Los Alamos Survival-Mortality experiment (SUMO) is located on Frijoles Mesa near

107 Los Alamos, New Mexico, USA, at an elevation of $2150 \mathrm{~m}$ (Garcia-Forner et al. 2015). The

108 experiment is located in a piñon-juniper woodland near the ponderosa pine (Pinus ponderosa)

109 forest ecotone. The tree community at SUMO is dominated by piñon pine (Pinus edulis

110 Engelm.) and one-seed juniper (Juniperus monosperma (Engelm.) Sarg.) with Gambel oak

111 (Quercus gambelli Nutt.) and the occasional ponderosa pine (Pinus ponderosa Douglas ex

112 C.Lawson), alligator juniper (Juniperus deppeana Steud.) and rocky mountain juniper (Juniperus 
113 scopulorum Sarg.) are also found. Soils are Hackroy clay loam and range in depth from 40 to 80 $114 \mathrm{~cm}$ above a parent material of volcanic tuff.

115 The SUMO experiment includes a below canopy rain-out structure that diverts $\sim 45 \%$ of

116 precipitation and 18 transparent open-top chambers (OTCs) regulated by heating and cooling

117 units (RJPL Package Heat Pump and RLPL Package Air Conditioner, Rheem Manufacturing

118 Company, Atlanta GA, USA) to enable temperature control (Garcia-Forner et al. 2015). The

119 rainout structure is similar in design to that described by Pangle et al (2012), but with troughs at

$120 \sim 1.3 \mathrm{~m}$ above the ground. Piñon pine and one-seed juniper trees were assigned to 5 treatments,

121 drought $(\sim 45 \%$ rain-out $)$, heat $\left(\sim+5^{\circ} \mathrm{C} \mathrm{OTC}\right)$, heat + drought $\left(\sim 45 \%\right.$ rain-out and $\sim+5^{\circ} \mathrm{C}$ OTC $)$,

122 ambient (ambient precipitation and temperature) and ambient chamber control (ambient

123 precipitation and $\sim+0^{\circ} \mathrm{C} \mathrm{OTC}$; Fig S1). OTCs maintained at ambient temperatures allowed

124 testing for any chamber effects independent of heating. Temperature was monitored by two

125 weather stations at the site and in each OTC at two height locations ( $1 \mathrm{~m}$ and 2/3 tree height;

126 CS215 Temperature and Relative Humidity Probe and CR1000 datalogger, Campbell Scientific,

127 Logan, UT, USA). This system was used as a thermostat to set desired temperature conditions in

128 chambers. Over the course of this study, the mean effect in the heated treatments (heat and

129 heat + drought) was $+4.77^{\circ} \mathrm{C}$ (Fig S2) and in the ambient chamber control was $-0.13^{\circ} \mathrm{C}$, relative to 130 ambient site conditions.

132 Environmental Conditions.

133 Treatments were initiated in June 2012 (Garcia-Forner et al. 2015), approximately nine

134 months prior to initial phenology and growth measurements in March of 2013. From 1987-2012, 135 mean annual temperature at SUMO was $10.5^{\circ} \mathrm{C}$, varying on average from $-0.6^{\circ} \mathrm{C}$ in December to 
136

137 (http://environweb.lanl.gov/weathermachine/). Precipitation at the site is influenced by the

138 North American Monsoon season and is highest from July to September with a relatively even

139 distribution throughout the rest of the year. Mean annual temperature in 2012, the year prior to

140 the study, was $12.2^{\circ} \mathrm{C}$ and total precipitation was $198 \mathrm{~mm}$. Mean annual temperature in 2013,

141 the year of this study, was $9.7^{\circ} \mathrm{C}$ and total precipitation was $426 \mathrm{~mm}$. However, $45 \%$ of annual

142 precipitation in $2013(194 \mathrm{~mm}$ ) fell in September (Fig S2), such that the majority of the 2013

143 growing season and study measurements occurred during a period of drought continuing from

1442011 (Williams et al. 2014).

145

146

147

148

149

150

151

152

153

154

155

156

157

\section{Phenology and Growth.}

For each treatment, eleven branches were selected among four piñon pine and juniper trees (2-3 per tree) for phenology and growth measurements. On each branch, we made measurements on the primary axis of growth, and also on a secondary axis that had 3-5 years of growth (measured in piñon pine, estimated in juniper) following the methods of Girard et al. (2011, 2012). After branch selection, initial measurements were made on March 16, 2013 (day of year (DOY) 75) and measurements were repeated periodically (every 9 to 29 days, mean sampling interval was $\sim 18$ days) throughout the 2013 growing season until November 19, 2013 (DOY 323). In branches of piñon pine, we noted phenophase (developmental stage) and measured the length of any new needles with a digital caliper. We described shoot phenophase using a numerical classification scheme adapted for piñon pine from the methods of Girard et al. (2011, 2012; Table 1, Fig S3). This scheme included the following stages: 1) bud dormant and unchanged in size, 2) bud swelling or growth observed, 3) needle scales open (budbreak), 4) new 
159 needle emergence and growth, 5) needle pairs separate. From these measurements we

160 determined the day of needle emergence for each branch (phenophase 4), and calculated the

161 proportion of branches which had needle growth for each piñon pine tree for each sampling date.

162 Concurrently, measurements of shoot length were also made with a digital caliper. For

163 piñon pine, we measured shoot length from the visible boundary that can be easily discerned in

164 this species between the previous year's growth and the base of the bud. As prior annual shoot

165 growth cannot be discerned visually in juniper, we marked the transition between green and

166 brown shoot tissue with ink, and measured from this mark to the tip of the growing shoot. In

167 both species we also noted the appearance of male and female reproductive structures and

168 calculated the percentage of measured branches with these. In juniper, male cones grow in late

169 summer for pollen release the following early spring, and we quantified the presence of both

1702013 and 2014 pollen cones in 2013. Branches of both species were also photographed

171 approximately each month.

172

173 Water potential

174 Plant water potential on each tree (four per treatment) was measured monthly during the

1752013 growing season to assess xylem water tension. Two twig samples were excised from the

176 south side of each tree before dawn and kept in a refrigerator at the site until measurement within

1772 hours of collection. Water potential was measured with a Scholander pressure chamber (PMS

178 Instruments, Albany, OR) and determined as the mean of the two samples for each tree. A

179 growing season mean in pre-dawn plant water potential was calculated from monthly

180 measurements taken in March through October 2013. 


\section{Non-structural carbohydrates.}

On June, 192013 (DOY 170), approximately 1 year after experimental treatments were initiated, tissue samples were collected from all trees in the study for non-structural carbohydrate (NSC) analysis. Foliar and shoot (twig) samples were collected by clipping recent canopy tissue. Bole and large root samples were collected with an increment borer. Roots samples were not obtained for some trees when roots of sufficient size for coring could not be found. All NSC samples were placed in liquid $\mathrm{N}_{2}$ after collection, transported to the laboratory on dry ice, stored at $-70^{\circ} \mathrm{C}$, microwaved for 5 minutes at $800 \mathrm{~W}$, and then dried at $65^{\circ} \mathrm{C}$ for 48 hours. All samples were ground into a fine powder using a ball mill (VWR, Radnor, PA), and woody samples were pre-ground with a Wiley mill (Thomas Scientific, Swedesboro, NJ). NSC, defined as soluble sugars (glucose, fructose, and sucrose) and starch, were assayed with water extraction and enzymatic quantification following a protocol modified from Hoch et al. (2002). Complete details of our NSC protocol were described by Dickman et al. (2015). Extraction was performed on $\sim 12 \mathrm{mg}$ of sample with $1.6 \mathrm{~mL}$ of deionized water for 1 hour in a $100^{\circ} \mathrm{C}$ water bath.

Quantification was achieved via NAD-linked enzymatic assay and spectral assessment at $340 \mathrm{~nm}$ (Varian Cary 50 UV-Vis spectrophotometer, Palo Alto, CA).

\section{Data analysis.}

Prior to data analysis, time series of phenology and growth data for each branch were checked and inconsistent or missing data were corrected from branch photographs if possible, or removed. All statistical analyses were performed in SPSS Statistic 22.0 (IBM, Amonk, NY) with an $\alpha$ of 0.05 . Before analysis, missing data were imputed conservatively by substituting the measurement recorded at the previous sampling date on the same branch. Repeated measures 
205 ANOVA was used in time series analysis of proportion of branches with needles, needle growth, 206 and shoot growth, with treatment (5 categories) and time as main fixed factors, and with Fisher's 207 LSD for post-hoc analysis. We used the Huynh-Feldt correction (Huynh and Feldt 1976) to 208 determine significance of results when unequal variance assumptions were violated (as 209 determined by Mauchly's test for sphericity). For day of needle emergence and percent of 210 branches with reproductive structures, data were analyzed with ANOVA using treatments as 211 factors and Fisher's LSD for post-hoc analysis. Data were analyzed using Kruskal-Wallis with

212 Dunn's test for post-hoc analysis if a Levene's test for unequal variance was significant. For 213 analysis of the relationships of NSC and water potential with phenology and growth metrics, we 214 calculated tree means of multiple branch data separately for the primary and secondary axes and 215 used linear regression.

217 Results.

218 Phenophase and needle emergence timing in piñon pine.

219 The proportion of piñon trees that had needle emergence was highest in ambient and 220 chamber control treatments for both primary and secondary branch axes $(p<0.001$, Fig 1). For

221 the primary axis, this proportion was lower than ambient in the drought and drought + heat

222 treatments $(\mathrm{p}<0.05)$, but not in the heat treatment $(\mathrm{p}>0.05$, Fig 1$)$. For the secondary axis

223 branches, the proportion of trees that had needle emergence was lower in the heat, drought, and 224 drought + heat treatments than in ambient or chamber controls $(\mathrm{p}<0.05)$. No needle emergence 225 was observed in selected secondary axis branches on trees in the drought + heat treatment (Fig 1).

226 Needle emergence on primary axis branches occurred earliest in ambient and control chamber 227 treatments, on average at DOY 196 (July 15) and 205 (July 24), respectively (Fig 2). Relative to 
228 ambient, needle emergence in primary axis branches in the drought, heat, and drought + heat

229 treatments was delayed on average by 19, 39, and 57 days, respectively ( $p<0.05$, Kruskal-

230 Wallis and Dunn's test, Fig 2). There were no significant differences in the emergence timing of

231 secondary axis branches among treatments, likely due to the large variability in responses and

232 the absence of needle growth in the drought + heat treatment $(\mathrm{p}>0.05)$. For both axes, standard

233 error around needle emergence timing is higher in heat, drought, and drought + heat treatments

234 relative to ambient, indicating increased variability with climate stress.

236 Needle and shoot growth.

237 In primary axis branches, piñon needle growth in the ambient and chamber control

238 treatments was greater than that in the drought, heat, and drought + heat treatments $(p<0.05$, Fig

239 3). For the secondary axis, there were no significant differences in piñon needle growth among

240 ambient, heat and drought trees $(\mathrm{p}>0.05)$. However, no piñon needle growth was observed in

241 drought + heat trees, and control chamber trees had higher needle growth than trees in the heat and

242 drought treatments for the secondary axis $(p<0.01$, Fig 3$)$. Shoot growth of piñon pine over the

243 course of 2013 was higher, and increased earlier, in the ambient and chamber control treatments

244 relative to the heat, drought, and drought+heat treatments for both primary and secondary axes ( $p$

$245<0.05$, Fig 4). For juniper, there was no difference in shoot growth among treatments $(\mathrm{p}>0.05)$,

246 and shoot growth was much lower than for piñon pine $(\mathrm{p}<0.001$, Fig 4).

248 Reproductive structures.

249 Observed differences in the growth of reproductive structures among treatments in both 250 species was minimal. We observed no female cone production for either species, and only one 
251 piñon branch in the control chamber treatment had male cones. We observed substantial

252 production of male cones in juniper, both early (cones produced in 2012 which released pollen in 253 early 2013) and later in the year (cones produced in 2013 for pollen release in early 2014, Fig

254 S3). There were no significant treatment effects on juniper male cone production for either year, 255 likely due to the high variability among trees and branches. In the drought + heat treatment, male 256 pollen cones were reduced from 2012 to 2013 on secondary axis branches $(\mathrm{p}<0.05$, Fig S4,

257 Kruskal-Wallis analysis with posthoc Dunn's test).

259 Phenology and Physiology Correlations.

260 Shoot and needle growth of piñon were positively correlated with pre-dawn water 261 potential while needle emergence timing was negatively correlated with water potential $(\mathrm{p}<$ 2620.05 , Fig 5a and c, Table S1). There were no correlations for juniper between shoot growth and 263 water potential $(\mathrm{p}>0.05)$. Correlations between shoot growth, needle growth, and needle 264 emergence timing were also found with soluble sugars, starch, and total NSC in bole, needle, and 265 shoot tissues $(\mathrm{p}<0.05$, Fig $5 \mathrm{~b}$ and d, Table S2). Growth measurements were positively 266 correlated with NSC components with one exception, an inverse relationship for primary axis 267 shoot growth with shoot glucose and fructose $(\mathrm{r}=-0.48, \mathrm{p}<0.05)$. Needle emergence timing 268 was negatively correlated with NSC variables in primary axis branches $(\mathrm{p}<0.05)$, but this 269 relationship was not significant for secondary axis branches $(\mathrm{p}>0.05)$. Shoot growth, needle 270 growth and needle emergence timing were most consistently correlated with shoot starch content 271 and these relationships generally had the highest correlation coefficients (Table S2, Fig 5c and 272 d). Although the distribution of points in Fig 5c and d suggests a non-linear relationship, non273 linear regression did not result in a statistical improvement over a linear trend. For juniper, only 
274 two correlations with NSC were found, shoot growth in secondary axis branches with shoot

275 glucose and fructose $(r=-0.53, \mathrm{p}<0.05)$ and with shoot total NSC $(\mathrm{r}=-0.46, \mathrm{p}<0.05$; data not

276 show). Monthly and mean growing season pre-dawn water potential were correlated with June

277 NSC variables by tissue in piñon pine (Table S3). Soluble sugars were inversely correlated with

278 water potential, but a greater number of tissue starch and total NSC variables were positively

279 correlated with water potential $(\mathrm{p}<0.05$, Table S3).

281 Discussion.

282 Overall, we found that experimental drought and heat reduced growth and delayed

283 phenological development of piñon pine, while juniper growth was unresponsive to treatment.

284 We hypothesized that increased temperature would lead to earlier development and increased

285 shoot and foliar growth. We found no support for this hypothesis in any measured phenological

286 or growth variable. In contrast, the heat treatment $\left(+4.8^{\circ} \mathrm{C}\right)$ reduced phenological development

287 in secondary axis branches (Fig 1), delayed needle emergence in primary axis branches (Fig 2),

288 reduced foliar growth (Fig 3), and reduced shoot growth (Fig 4) in piñon pine relative to the

289 ambient treatment. These results contrast starkly with findings from much phenological

290 research, predominately from more mesic ecosystems where increased temperature was

291 associated with earlier development and/or increased growth (Aono and Kazui 2008, Miller-

292 Rushing and Primack 2008, Gordo and Sanz 2009, Primack et al. 2009, Richardson et al. 2013,

293 Keenan et al. 2014). Our results demonstrate that this paradigm may not apply for trees in drier

294 regions.

295 Drought alone delayed phenological development and reduced foliar growth (primary

296 axis), and shoot growth, relative to the ambient treatment, consistent with our hypothesis (Figs 1- 
297 4). Moreover, there were no differences in any measured variable between the heat and drought

298 treatments in either branch axis, indicating that these two stresses affected the growth and

299 phenology of piñon pine similarly. Our results were consistent with the phenological and growth

300 responses of several Mediterranean tree species to experimental and natural drought (Borghetti et

301 al. 1998, Ogaya and Peñuelas 2004, Peñuelas et al. 2004, Girard et al. 2011, 2012).

Given that the heat and drought treatments both delayed development and reduced growth it was surprising that the drought + heat treatment did not have more of a synergistic effect

304 on piñon pine (Figs 1-4). The effects of heat and drought were most striking for foliar

305 development, where heat delayed emergence by 19 days, drought by 39 days, and drought + heat

306 by 57 days in the primary axis branches (Fig 2), while in secondary axis branches in the

307 drought + heat treatment had no needle growth at all in 2013 (Figs 1 and 2). Although evergreen

308 conifers can still photosynthesize with previous years' foliar growth, these trees went without the

309 higher photosynthetic efficiency of younger foliage for part or all of the growing season (Ethier

310 et al. 2006, Warren 2006).

311 Experiments have been found to under predict advances in leaf-flushing from warming,

312 perhaps due to treatment artifacts (Wolkovich et al 2012). We found no differences in response

313 between our ambient and chamber control treatment making this explanation for our results less

314 likely. Previous research has shown that advances in development from heating can be reduced

315 as temperature increases from $\sim+1$ to $\sim+3^{\circ} \mathrm{C}$ (Repo et al. 1996, Morin et al. 2010, Kuster et al.

316 2014), and our temperature treatment was $\sim+4.8^{\circ} \mathrm{C}$. Our result of reduced growth in the heated

317 treatment is consistent with previous research finding that that radial growth of piñon pine and

318 other conifers in the southwest US is negatively correlated with temperature (Adams and Kolb

319 2005, Williams et al. 2013). 
Our phenology and growth results should be considered in the context of the unusually

321 dry climate of 2011, 2012, and 2013 prior to September (Fig S2; Williams et al. 2014). From

322 January through August 2013 the SUMO experiment site received only $146 \mathrm{~mm}$ of precipitation,

$32351 \%$ of the 25 -year mean of $284 \mathrm{~mm}$ for the same period. Prior to this, 2012 annual precipitation

324 was only $48 \%$ of the 25 -year mean. Thus for the majority of 2013 , our heat and drought

325 treatments were imposed on top of an already strong drought. Effects of this background

326 drought on the ambient trees in our experiment may explain why we did not observe any earlier

327 development or increased growth in the heat treatment for piñon pine, relative to the ambient

328 treatment. The lack of any reproductive development in ambient piñon, despite our observations

329 that male pollen cones were common in 2012 in these trees, could also be explained by the dry

330 start to 2013. The low precipitation in 2011-2013 may also explain the low shoot growth of

331 juniper, relative to piñon pine, and also the lack of any treatment effect in juniper shoot growth.

332 Juniper is known for its highly conservative growth in dry years (Howell 1941, Herman 1956).

333 This conservative growth strategy likely enables juniper's survival at hotter and drier sites than

334 piñon pine. Notably, the conditions in the drought +heat treatment during the already dry 2013

335 were not unrealistic, but analogous to those anticipated with future warming in megadrought

336 climate conditions projected for later in the century (Williams et al. 2013, Cook et al. 2015).

337 Consistent with our hypothesis, lower values of water potential appeared to constrain

338 growth and timing of needle emergence in piñon pine (Fig 5, Table S1). Correlation coefficients

339 were typically highest for mean growing season water potential, and values in the months of

340 March, May, June, and August were consistently correlated with growth and phenology,

341 indicating that physiological drought stress over the entire growing season influenced growth and 
342 development (Fig 5, Table S1). In juniper, low observable variability in growth likely

343 contributed to the lack of correlation with water potential.

344 We hypothesized that non-structural carbohydrates (NSC) would be unrelated to growth

345 and phenology, or that reduced growth and delayed development due to drought stress would be

346 associated with increased NSC, consistent with a reduction in C sink demand preceding a C

347 source limitation (Körner 2003, Fatichi et al. 2014). However, low NSC in June was correlated

348 with reduced growth and delayed needle emergence in piñon pine (Table S2). Correlations were

349 strongest and most consistent across growth and phenology variables for shoot starch (Fig 5),

350 indicating that trees with higher NSC reserves in shoots in the dry early growing season were

351 more likely to show earlier needle emergences and greater growth over the rest of the season.

352 This relationship, while unexpected given previous results from some species (e.g. Körner 2003),

353 is consistent with reduced NSC in piñon pine observed in response to seasonal and prolonged

354 drought stress (Adams et al. 2013, Sevanto et al. 2014, Dickman et al. 2015). The response of

355 piñon is not unique; Mediterranean Arbutus unedo with low lignotuber NSC following 14 years

356 of experimental drought had reduced basal area increment growth (Rosas et al. 2013). Despite

357 low variability in juniper growth, we found two significant positive correlations of shoot growth

358 with shoot glucose and fructose, and total NSC, indicating that higher juniper growth was related

359 to increased NSC. Glucose and fructose have been shown to increase in juniper in response to

360 drought and may be important for osmotic adjustment that enables growth under drought

361 conditions in this species (Dickman et al. 2015). The paucity of significant relationships in this

362 species is consistent with our hypothesis that NSC would be primarily unrelated to growth.

363 We urge caution in interpreting positive (inverse) relationships between growth (needle

364 emergence timing) and NSC in these trees as a source limitation. We have correlated growth 
365 with NSC from relatively early in the growing season (June $19^{\text {th }}$, DOY 170). At this time for

366 piñon pine, some shoot growth had been observed in the ambient and control chamber

367 treatments, but needle emergence had not yet occurred in any measured branches. It is possible

368 that NSC increased later in the growing season in trees which had reduced growth. June NSC

369 and its components were correlated with shoot water potential across the growing season (Table

370 S3), complicating the attribution of causation. For all cases where a significant relationship was

371 found for both mean growing season water potential and shoot starch with growth or needle

372 emergence (Fig 5), the adjusted $r^{2}$ from a linear regression was always higher for the correlation

373 with water potential than for that with shoot starch concentration. This indicates that direct

374 drought stress on xylem water tension was a stronger constraint for growth and development than 375 NSC.

376 Our results demonstrate that a $4.8 \mathrm{C}$ increase in temperature, a change consistent with

377 climate projections for 2100 in many regions with increasing anthropogenic $\mathrm{CO}_{2}$ emissions

378 (IPCC 2013), can cause phenological delay and reduced growth. Moreover, drought in

379 combination with elevated temperature resulted in either a $\sim 2$ month delay in needle emergence

380 or a complete lack of needle growth in piñon pine, which would cause a severe reduction in tree

381 vigor over multiple growing seasons. These strong effects were observed after only $\sim 1$ year of

382 treatment, demonstrating that phenological and growth responses to temperature and drought

383 stress can be rapid. Our results indicate that projections based on typical phenological responses

384 of an earlier and longer growing season in response to higher temperatures, and consequent

385 increased ecosystem $\mathrm{C}$ sink strength, may not be valid for regions where plants will face

386 increased drought stress with future climate change (Weiss et al. 2012). Trees that experience

387 growth reductions from drought and temperature stress have reduced vigor and are often more 
388 prone to drought-induced mortality (Manion 1980, Waring 1987, Macalady and Bugmann 2014).

389 Outside of the Mediterranean region, phenological responses of semi-arid tree species to drought

390 and temperature have not been well-studied, and our results highlight the need to evaluate these

391 tree responses in other dry regions. The physiological link between xylem tension and

392 phenological response could provide a mechanistic, process-based approach to account for

393 drought- and temperature-induced developmental delay and reduced productivity in global

394 vegetation models. Correctly representing such phenological feedbacks on the terrestrial C sink

395 with a changing climate is necessary for robust projections of global climate change.

397 Acknowledgments.

398 The Los Alamos Survival-Mortality Experiment (SUMO) is funded by the US Department of 399 Energy, Office of Science, Biological and Environmental Research. This research was also 400 supported by funding from Los Alamos National Laboratory Directed Research, including the 401 postdoctoral program, and the US DOE, Office of Science, Science Undergraduate Laboratory 402 Internship program.

403

404 References.

405 Adams HD, Kolb TE (2005) Tree growth response to drought and temperature in a mountain 406 landscape in northern Arizona, USA. Journal of Biogeography, 32, 1629-1640.

407 Adams HD, Germino MJ, Breshears DD, Barron-Gafford GA, Guardiola-Claramonte M, Zou 408 CB, Huxman TE (2013) Nonstructural leaf carbohydrate dynamics of Pinus edulis 
during drought-induced tree mortality reveal role for carbon metabolism in mortality mechanism. New Phytologist, 197, 1142-1151.

411 Aono Y, Kazui K (2008) Phenological data series of cherry tree flowering in Kyoto, Japan, and

412 its application to reconstruction of springtime temperatures since the 9th century.

413 International Journal of Climatology, 28, 905-914.

414 Borghetti M, Cinnirella S, Magnani F, Saracino A (1998) Impact of long-term drought on xylem embolism and growth in Pinus halepensis Mill. Trees-Structure and Function, 12, 187-

Cook BI, Ault TR, Smerdon JE (2015) Unprecedented $21^{\text {st }}$ century drought risk in the American Southwest and Central Plains. Science Advances, 1, e1400082. warming and drought on carbon balance related to wood formation in black spruce. Annals of Botany, 114, 335-345.

Dickman LT, McDowell NG, Sevanto S et al. (2015) Carbohydrate dynamics and mortality in a piñon-juniper woodland under three future precipitation scenarios. Plant Cell and Environment, 38, 729-739.

Ethier GJ, Livingston NJ, Harrison DL, Black TA, Moran JA (2006) Low stomatal and internal conductance to $\mathrm{CO} 2$ versus Rubisco deactivation as determinants of the photosynthetic decline of ageing evergreen leaves. Plant Cell and Environment, 29, 2168-2184. 
428 Fatichi S, Leuzinger S, Körner C (2014) Moving beyond photosynthesis: from carbon source to sink-driven vegetation modeling. New Phytologist, 201, 1086-1095.

430 Garcia-Forner N, Adams HD, Sevanto S et al. (2015) Response of two semi-arid conifer tree species to reduced precipitation and warming reveal new perspectives for stomatal regulation. Plant, Cell, and Environment, In review.

433 Girard F, Vennetier M, Guibal F, Corona C, Ouarmim S, Herrero A (2012) Pinus halepensis Mill. crown development and fruiting declined with repeated drought in Mediterranean France. European Journal of Forest Research, 131, 919-931.

Girard F, Vennetier M, Ouarmim S, Caraglio Y, Misson L (2011) Polycyclism, a fundamental tree growth process, decline with recent climate change: the example of Pinus halepensis

439 Gordo O, Sanz JJ (2009) Long-term temporal changes of plant phenology in the Western Mediterranean. Global Change Biology, 15, 1930-1948.

441 Gruber A, Pirkebner D, Florian C, Oberhuber W (2012) No evidence for depletion of carbohydrate pools in Scots pine (Pinus sylvestris L.) under drought stress. Plant Biology, 14, 142-148.

444 Guak S, Olsyzk DM, Fuchigami LH, Tingey DT (1998) Effects of elevated CO(2) and 445 temperature on cold hardiness and spring bud burst and growth in Douglas-fir (Pseudotsuga menziesii). Tree Physiology, 18, 671-679. 
447 Han S, Chung H, Noh NJ et al. (2014) Effect of open-field experimental warming on the leaf 448 phenology of oriental oak (Quercus variabilis) seedlings. Journal of Plant Ecology, 7, $449 \quad 559-566$.

450 Hartmann H, McDowell NG, Trumbore S (2015) Allocation to carbon storage pools in Norway 451 spruce saplings under drought and low CO2. Tree Physiology, In press.

452 Herman FR (1956) Growth and phenological observation of Arizona junipers. Ecology, 37, 193453195.

454 Hoch G, Popp M, Körner C (2002) Altitudinal increase of mobile carbon pools in Pinus cembra 455 suggests sink limitation of growth at the Swiss treeline. Oikos, 98, 361-374.

Howell J (1941) Piñon and juniper woodlands of the Southwest. Journal of Forestry, 39, 542545.

Huynh H, Feldt LS (1976) Estimation of the box correction for degrees of freedom from sample data in randomized block and split-plot designs. Journal of Education and Behavioral Statistics, 1, 69-82.

Intergovernmental Panel on Climate Change (IPCC) (2013) Climate Change 2013: The Physical IPCC. Cambridge, UK: Cambridge University Press.

464 Keeling CD (1960) The concentration and isotopic abundances of carbon dioxide in the 465 atmosphere. Tellus, 12, 200-203. 
466 Keeling CD, Chin JFS, Whorf TP (1996) Increased activity of northern vegetation inferred from 467 atmospheric CO2 measurements. Nature, 382, 146-149.

468 Keenan TF, Gray J, Friedl MA et al. (2014) Net carbon uptake has increased through warming469 induced changes in temperate forest phenology. Nature Climate Change, 4, 598-604.

470 Körner C (2003) Carbon limitation in trees. Journal of Ecology, 91, 4-17.

471 Kuster TM, Dobbertin M, Gunthardt-Goerg MS, Schaub M, Arend M (2014) A phenological 472 timetable of oak growth under experimental drought and air warming. Plos One, 9.

473 Limousin J-M, Rambal S, Ourcival J-M et al. (2012) Morphological and phenological shoot 474 plasticity in a Mediterranean evergreen oak facing long-term increased drought. $475 \quad$ Oecologia, 169, 565-577.

476 Macalady AK, Bugmann H (2014) Growth-mortality relationships in piñon pine (Pinus edulis) 477 during severe droughts of the past century: shifting processes in space and time. Plos $478 \quad$ One, $9,17$.

479 Manion PD (1980) Tree Disease Concepts. Prentice Hall Career \& Technology, Englewood $480 \quad$ Cliffs, New Jersey.

481 McDowell NG (2011) Mechanisms linking drought, hydraulics, carbon metabolism, and 482 vegetation mortality. Plant Physiology, 155, 1051-1059.

483 Miller-Rushing AJ, Primack RB (2008) Global warming and flowering times in Thoreau's 484 concord: A community perspective. Ecology, 89, 332-341. 
485 Morin X, Roy J, Sonie L, Chuine I (2010) Changes in leaf phenology of three European oak species in response to experimental climate change. New Phytologist, 186, 900-910.

487 Norby RJ, Hartz-Rubin JS, Verbrugge MJ (2003) Phenological responses in maple to experimental atmospheric warming and $\mathrm{CO} 2$ enrichment. Global Change Biology, 9, 1792-1801.

Oberhuber W, Swidrak I, Pirkebner D, Gruber A (2011) Temporal dynamics of nonstructural carbohydrates and xylem growth in Pinus sylvestris exposed to drought. Canadian Journal of Forest Research-Revue Canadienne De Recherche Forestiere, 41, 1590-1597.

Ogaya R, Peñuelas J (2004) Phenological patterns of Quercus ilex, Phillyrea latifolia, and Arbutus unedo growing under a field experimental drought. Ecoscience, 11, 263-270.

Oleoson KW, Lawrence DM, Bonan GB (2013) Technical description of version 4.5 of the Community Land Model (CLM). Technical Note, NCAR/TN-503+STR, National Center for Atmospheric Research,

Overpeck J, Udall B (2010) Dry Times Ahead. Science, 328, 1642-1643. New Phytologist, 201, 1096-1100. the Mediterranean region. Global Change Biology, 8, 531-544. 
503 Peñuelas J, Filella I, Zhang XY et al. (2004) Complex spatiotemporal phenological shifts as a 504 response to rainfall changes. New Phytologist, 161, 837-846.

505

506

507

508

509

510
Pangle RE, Hill JP, Plaut JA et al. (2012) Methodology and performance of a rainfall manipulation experiment in a pinon-juniper woodland. Ecosphere,3, Article 28.

Primack RB, Higuchi H, Miller-Rushing AJ (2009) The impact of climate change on cherry trees and other species in Japan. Biological Conservation, 142, 1943-1949.

Repo T, Hanninen H, Kellomaki S (1996) The effects of long-term elevation of air temperature and CO2 on the frost hardiness of Scots pine. Plant Cell and Environment, 19, 209-216.

Richardson AD, Anderson RS, Arain MA et al. (2012) Terrestrial biosphere models need better representation of vegetation phenology: results from the North American Carbon Program Site Synthesis. Global Change Biology, 18, 566-584.

Richardson AD, Black TA, Ciais P et al. (2010) Influence of spring and autumn phenological transitions on forest ecosystem productivity. Philosophical Transactions of the Royal Society B-Biological Sciences, 365, 3227-3246.

Richardson AD, Keenan TF, Migliavacca M, Ryu Y, Sonnentag O, Toomey M (2013) Climate change, phenology, and phenological control of vegetation feedbacks to the climate system. Agricultural and Forest Meteorology, 169, 156-173.

Rosas T, Galiano L, Ogaya R, Peñuelas J, Martinez-Vilalta J (2013) Dynamics of non-structural carbohydrates in three Mediterranean woody species following long-term experimental drought. Frontiers in Plant Science, 4. 
523 Schaber J, Badeck FW (2003) Physiology-based phenology models for forest tree species in

524 Germany. International Journal of Biometeorology, 47, 193-201.

525 Sevanto S, Mcdowell NG, Dickman LT, Pangle R, Pockman WT (2014) How do trees die? A

526 test of the hydraulic failure and carbon starvation hypotheses. Plant Cell and

$527 \quad$ Environment, 37, 153-161.

528 Tissue DT, Wright SJ (1995) Effect of seasonal water availability on phenology and the annual

529 shoot carbohydrate cycle of tropical forest shrubs. Functional Ecology, 9, 518-527.

530 Waring RH (1987) Characteristics of trees predisposed to die. Bioscience, 37, 569-574.

531 Warren CR (2006) Why does photosynthesis decrease with needle age in Pinus pinaster? Trees532 Structure and Function, 20, 157-164.

533 Weiss JL, Betancourt JL, Overpeck JT (2012) Climatic limits on foliar growth during major 534 droughts in the southwestern USA. Journal of Geophysical Research$535 \quad$ Biogeosciences, 117, 15.

536 Williams AP, Allen CD, Macalady AK et al. (2013) Temperature as a potent driver of regional 537 forest drought stress and tree mortality. Nature Climate Change, 3, 292-297.

538 Williams AP, Seager R, Berkelhammer M et al. (2014) Causes and implications of extreme 539 atmospheric moisture demand during the record-breaking 2011 wildfire season in the 540 southwestern United States. Journal of Applied Meteorology and Climatology, 53, 2671$541 \quad 2684$. 
542 Wolkovich EM, Cook BI, Allen JM et al. (2012) Warming experiments underpredict plant

543 phenological responses to climate change. Nature, 485, 494-497.

544 Würth MKR, Pelaez-Riedl S, Wright SJ, Körner C (2005) Non-structural carbohydrate pools in 545 a tropical forest. Oecologia, 143, 11-24.

\section{Supporting Information.}

549 Table S1. Correlations between water potential and shoot growth, needle growth, and emergence 550 timing.

551 Table S2. Correlations between NSC and components and shoot growth, needle growth, and 552 emergence timing.

553 Table S3. Correlations between water potential and NSC components.

554 Fig S1. Design of the Los Alamos Survival-Mortality experiment.

555 Fig S2. Daily means in temperature and vapor pressure deficit for the ambient and heated 556 treatments, and total daily precipitation at the SUMO experiment in 2013.

557 Fig S3. An illustration of phenological phases in our classification scheme for piñon pine 558 Fig S4. Pollen cone production in one-seed juniper by treatment. 


\section{Figures and Tables}

561 Table 1. Phenophase descriptions of piñon pine shoot development. This classification scheme

562 was adapted for piñon pine from Girard et al. $(2011,2012)$. Photographic examples of

563 phenophases in piñon pine are shown in Fig S3.

\begin{tabular}{ll}
\hline Phenophase & Description \\
\hline $\mathbf{1}$ & Bud dormant and unchanged in size \\
$\mathbf{2}$ & Bud swelling or growth observed \\
$\mathbf{3}$ & Needle scales open (budbreak) \\
$\mathbf{4}$ & Needle emergence \\
$\mathbf{5}$ & Needle pairs separate \\
\hline
\end{tabular}

565 Fig 1. The proportion of piñon pine shoots with needle emergence (phenophase $>4$, Table 1) on

566 primary and secondary branches over the 2013 growing season under 5 environmental

567 treatments. Significant differences among treatments (over the growing season) are indicated by

568 letters separately for both primary and secondary axis branches (repeated measures ANOVA, p $<$

569 0.05). Phenophase classification is defined in Table 1 and illustrated in Fig S3. Overlapping

570 values are offset slightly to illustrate all treatments. Error bars are standard errors.

572 Fig 2. Timing of needle emergence for primary (black) and secondary (gray) axis branches.

573 Significant differences were found for needle emergence timing in the primary, but not

574 secondary, axis branches, and are indicated with letters (Kruskal-Wallis analysis and posthoc

575 Dunn's test). Note that no needle growth was observed in secondary axis branches in the

576 drought + heat treatment during the 2013 growing season. Error bars are standard errors. 
578 Fig 3. Piñon pine needle elongation on primary and secondary axis shoots over the 2013

579 growing season under 5 environmental treatments for shoots that had needle emergence.

580 Significant differences among treatments (over the growing season) are indicated by letters

581 separately for both primary and secondary axis branches (repeated measures ANOVA, $\mathrm{p}>0.05$ ).

582 Piñon pine trees under ambient conditions had greater needle elongation than trees in the heat,

583 drought, and drought+heat treatments on the primary axis, and the drought treatment on the

584 secondary axis. A line is shown at zero for the lack of needle growth observed on secondary axis

585 shoots in the drought + heat treatment; this was not included in statistical analysis. The occasional

586 appearance of decline in mean needle growth over the growing season is due to the error in the

587 growth measurement. Error bars are standard errors.

589 Fig 4. Shoot growth on primary and secondary axis branches of piñon pine (Pinus edulis) and

590 one-seed juniper (Juniperus monosperma) over the 2013 growing season under 5 environmental

591 treatments. Shoot growth increased significantly in both species over the growing season

592 (repeated measures ANOVA, $\mathrm{p}<0.001$ ). Treatment effects and treatment by time interactions

593 were significant only for piñon pine $(\mathrm{p}<0.001)$. Letters indicate significant differences in effects

594 among treatments for piñon pine over the growing season; shoot growth was reduced in the heat,

595 drought, and drought + heat treatments, relative to control treatments $(\mathrm{p}<0.05)$. The occasional

596 appearance of decline in mean shoot growth over time is a due to the error in the growth

597 measurement. Error bars are standard errors.

598

599 Fig 5. Relationships in piñon pine between mean growing season pre-dawn water potential $\left(\Psi_{\text {pd }}\right)$

600 and growth (a), June twig starch concentration and growth (b), mean growing season $\Psi_{\mathrm{pd}}$ and 
601 timing of needle emergence (c), and June twig starch concentration and timing of needle

602 emergence (d), for primary (red) and secondary axis (blue) branches. Relationships with growth

603 are shown for both shoots (circle, solid line) and needles (triangle, dashed line) in a and b.

604 Significant linear regressions between water potential and primary axis shoot $\left(\mathrm{r}^{2}=0.39\right)$ and

605 needle $\left(r^{2}=0.45\right)$ growth, secondary shoot $\left(r^{2}=0.51\right)$ and needle $\left(r^{2}=0.68\right)$ growth, and primary

606 needle emergence timing $\left(r^{2}=0.49\right)$ are shown in a and c. Significant linear regressions between

607 June twig starch concentration and primary axis shoot $\left(\mathrm{r}^{2}=0.24\right)$ and needle $\left(\mathrm{r}^{2}=0.29\right)$ growth,

608 secondary shoot $\left(r^{2}=0.39\right)$ and needle $\left(r^{2}=0.59\right)$ growth, and primary needle emergence timing

$609\left(r^{2}=0.43\right)$ are shown in $\mathbf{b}$ and $\mathbf{d}$. Additional growth and phenology correlations with water

610 potential and non-structural carbohydrate components for bole, needle, root and twig tissues are

611 found in Tables S1 and S2. Analogous relationships for juniper shoot growth were not observed

612 and are not shown $(\mathrm{p}>0.05)$.

613 


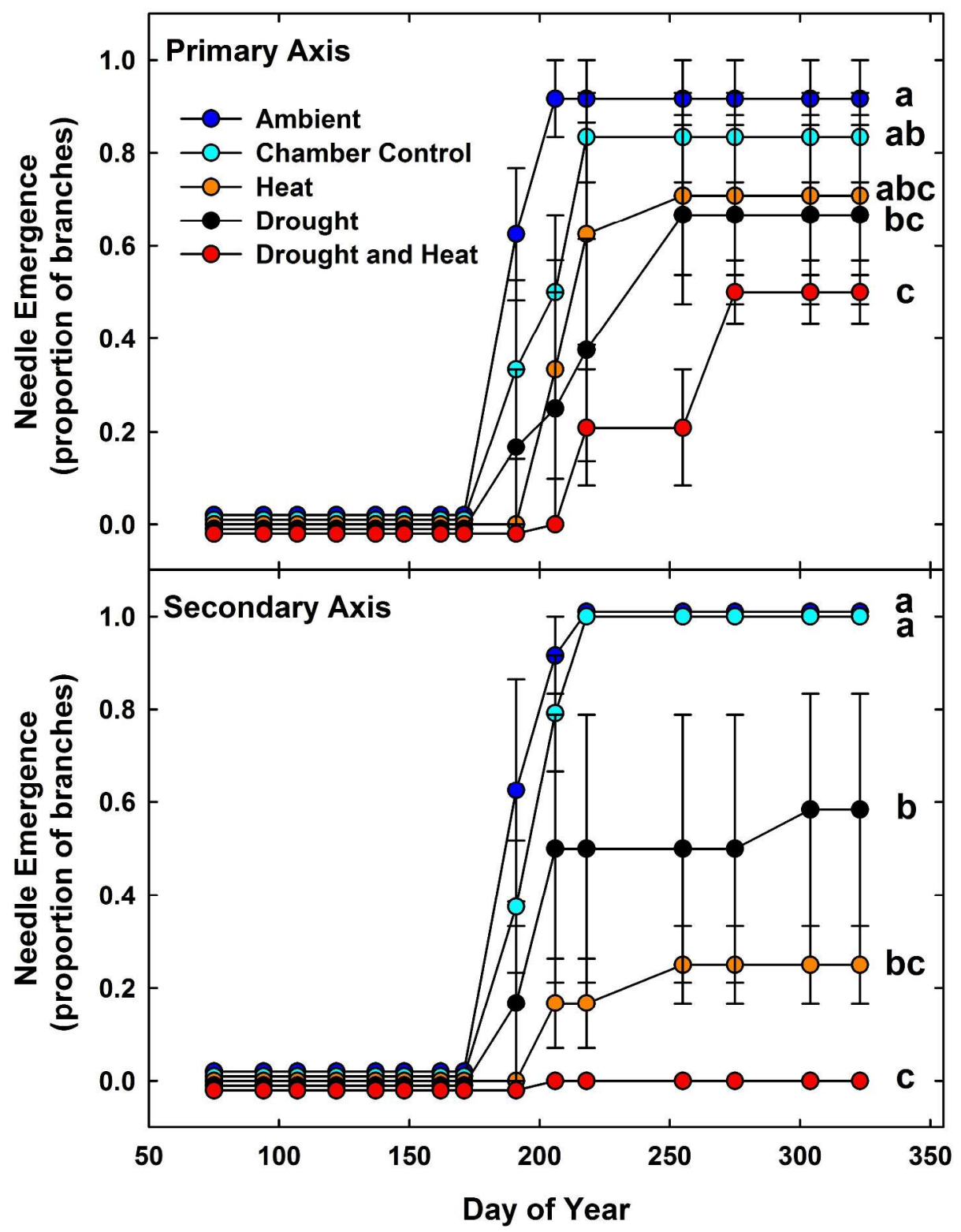

Fig 1. The proportion of piñon pine shoots with needle emergence (phenophase $>4$, Table 1 ) on primary and secondary branches over the 2013 growing season under 5 environmental treatments. Significant differences among treatments (over the growing season) are indicated by letters separately for both primary and secondary axis branches (repeated measures ANOVA, $p<0.05$ ). Phenophase classification is defined in

Table 1 and illustrated in Fig S3. Overlapping values are offset slightly to illustrate all treatments. Error bars are standard errors. $611 \times 786 \mathrm{~mm}(150 \times 150 \mathrm{DPI})$ 


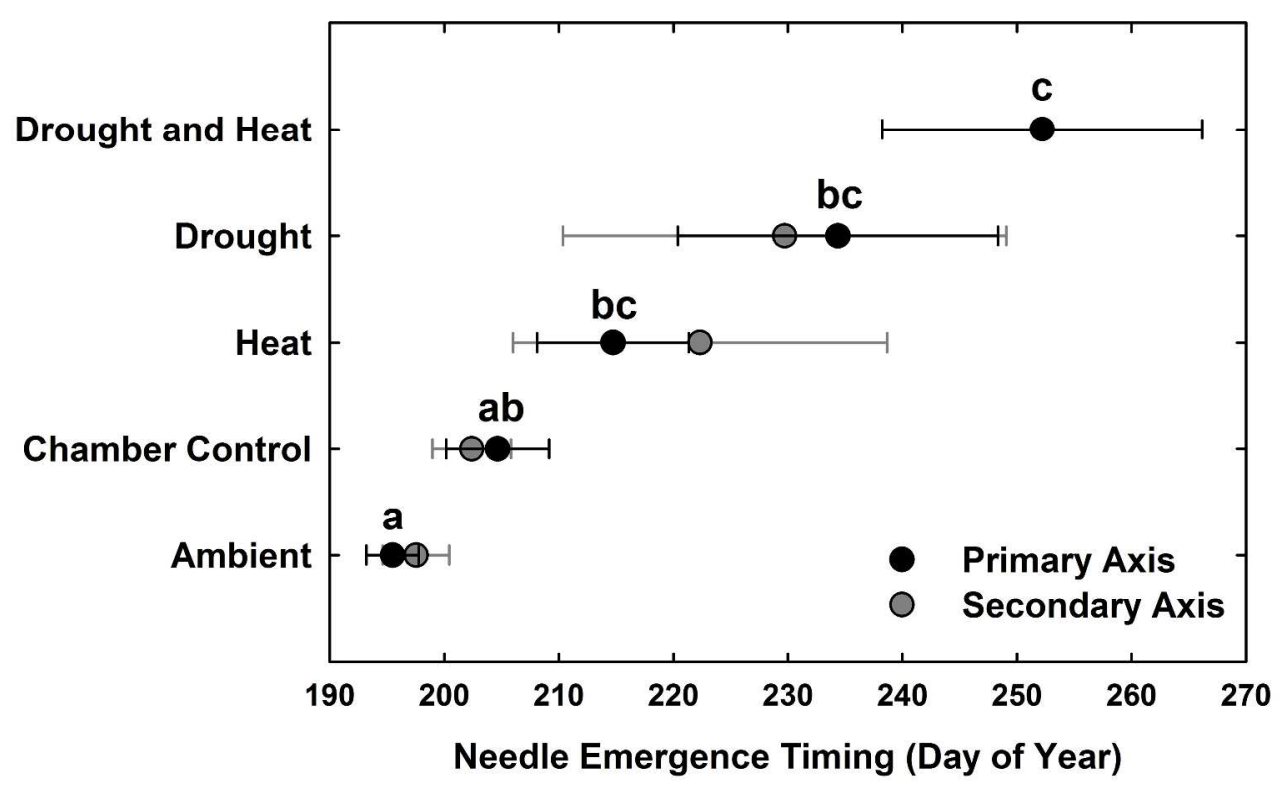

Fig 2. Timing of needle emergence for primary (black) and secondary (gray) axis branches. Significant differences were found for needle emergence timing in the primary, but not secondary, axis branches, and are indicated with letters (Kruskal-Wallis analysis and posthoc Dunn's test). Note that no needle growth was observed in secondary axis branches in the drought+heat treatment during the 2013 growing season. Error bars are standard errors.

$721 \times 434 \mathrm{~mm}(150 \times 150 \mathrm{DPI})$ 


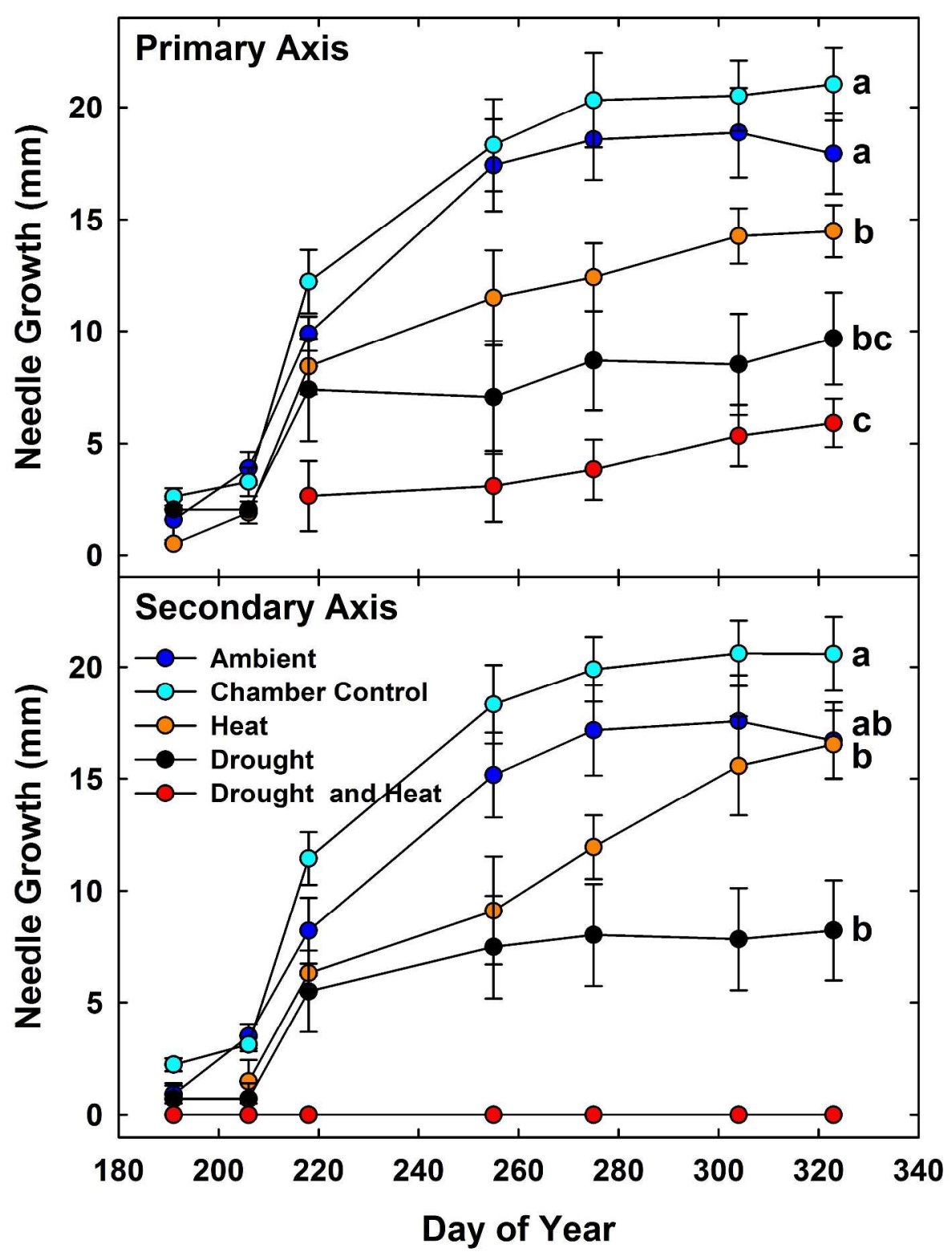

Fig 3. Piñon pine needle elongation on primary and secondary axis shoots over the 2013 growing season under 5 environmental treatments for shoots that had needle emergence. Significant differences among treatments (over the growing season) are indicated by letters separately for both primary and secondary axis branches (repeated measures ANOVA, $\mathrm{p}>0.05$ ). Piñon pine trees under ambient conditions had greater needle elongation than trees in the heat, drought, and drought+heat treatments on the primary axis, and the drought treatment on the secondary axis. A line is shown at zero for the lack of needle growth observed on secondary axis shoots in the drought+heat treatment; this was not included in statistical analysis. The occasional appearance of decline in mean needle growth over the growing season is due to the error in the growth measurement. Error bars are standard errors. 


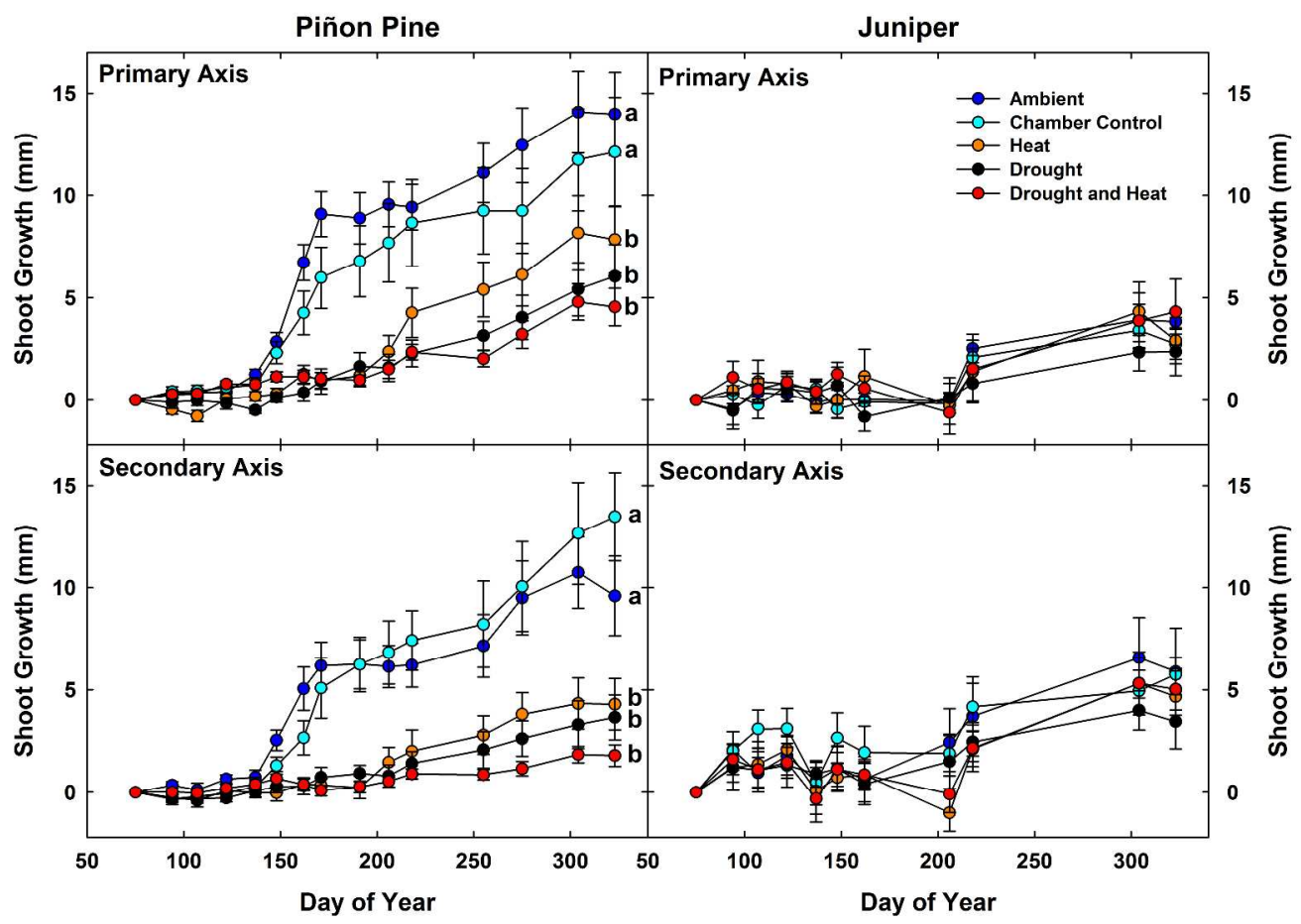

Fig 4. Shoot growth on primary and secondary axis branches of piñon pine (Pinus edulis) and one-seed juniper (Juniperus monosperma) over the 2013 growing season under 5 environmental treatments. Shoot growth increased significantly in both species over the growing season (repeated measures ANOVA, $p<$

$0.001)$. Treatment effects and treatment by time interactions were significant only for piñon pine ( $p$

$<0.001$ ). Letters indicate significant differences in effects among treatments for piñon pine over the growing season; shoot growth was reduced in the heat, drought, and drought+heat treatments, relative to control treatments $(p<0.05)$. The occasional appearance of decline in mean shoot growth over time is a due to the error in the growth measurement. Error bars are standard errors.

$1168 \times 826 \mathrm{~mm}(150 \times 150 \mathrm{DPI})$ 


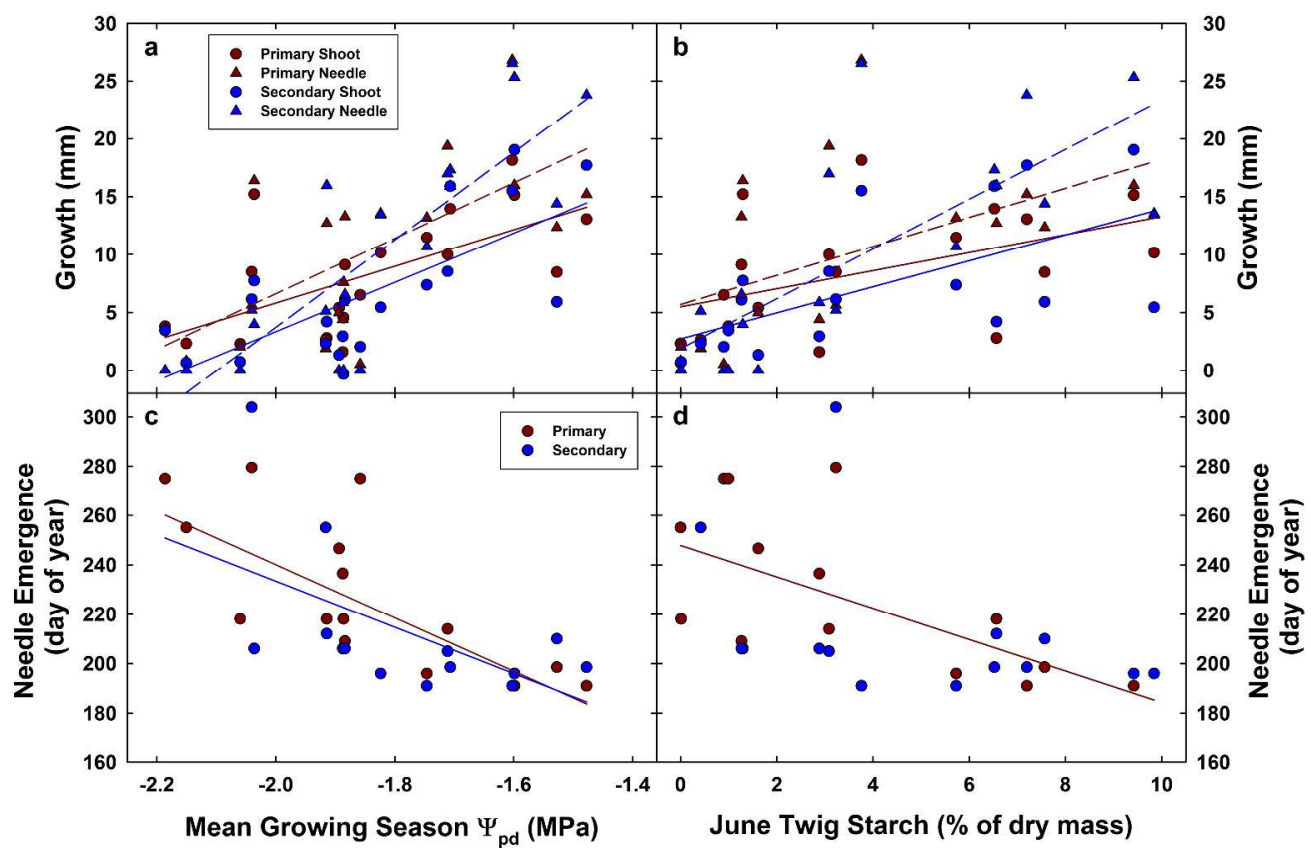

Fig 5. Relationships in piñon pine between mean growing season pre-dawn water potential $(\Psi p d)$ and growth (a), June twig starch concentration and growth (b), mean growing season $\Psi$ pd and timing of needle emergence (c), and June twig starch concentration and timing of needle emergence (d), for primary (red) and secondary axis (blue) branches. Relationships with growth are shown for both shoots (circle, solid line) and needles (triangle, dashed line) in a and b. Significant linear regressions between water potential and primary axis shoot $(r 2=0.39)$ and needle $(r 2=0.45)$ growth, secondary shoot $(r 2=0.51)$ and needle ( $r 2$ $=0.68)$ growth, and primary needle emergence timing $(r 2=0.49)$ are shown in a and $c$. Significant linear regressions between June twig starch concentration and primary axis shoot $(r 2=0.24)$ and needle $(r 2=$ $0.29)$ growth, secondary shoot $(r 2=0.39)$ and needle $(r 2=0.59)$ growth, and primary needle emergence timing $(r 2=0.43)$ are shown in $b$ and $d$. Additional growth and phenology correlations with water potential and non-structural carbohydrate components for bole, needle, root and twig tissues are found in Tables S1 and S2. Analogous relationships for juniper shoot growth were not observed and are not shown ( $p>$ 0.05). 
1 Experimental drought and heat can delay phenological development and reduce growth in

2 semiarid trees.

3

4 Henry D. Adams ${ }^{1}$, Adam D. Collins ${ }^{1}$, Samuel P. Briggs ${ }^{1}$, Michel Vennetier ${ }^{2}$, L. Turin Dickman ${ }^{1}$,

5 Sanna A. Sevanto ${ }^{1}$, Núria Garcia-Forner ${ }^{3,4}$, Nate G. McDowell ${ }^{1}$.

6

$7 \quad{ }^{1}$ Earth and Environmental Sciences, Los Alamos National Laboratory, Los Alamos, NM USA

$8 \quad{ }^{2}$ Irstea, UR Ecosystèmes Méditerranéens et Risques, Aix-en-Provence, France

$9{ }^{3}$ Centre de Recerca Ecològica i Aplicacions Forestals (CREAF), Cerdanyola del Vallès, Spain

10 Universitat Autònoma de Barcelona, Cerdanyola del Vallès, Spain

11

12 Supporting Information.

13

14 


\section{Precipitation}

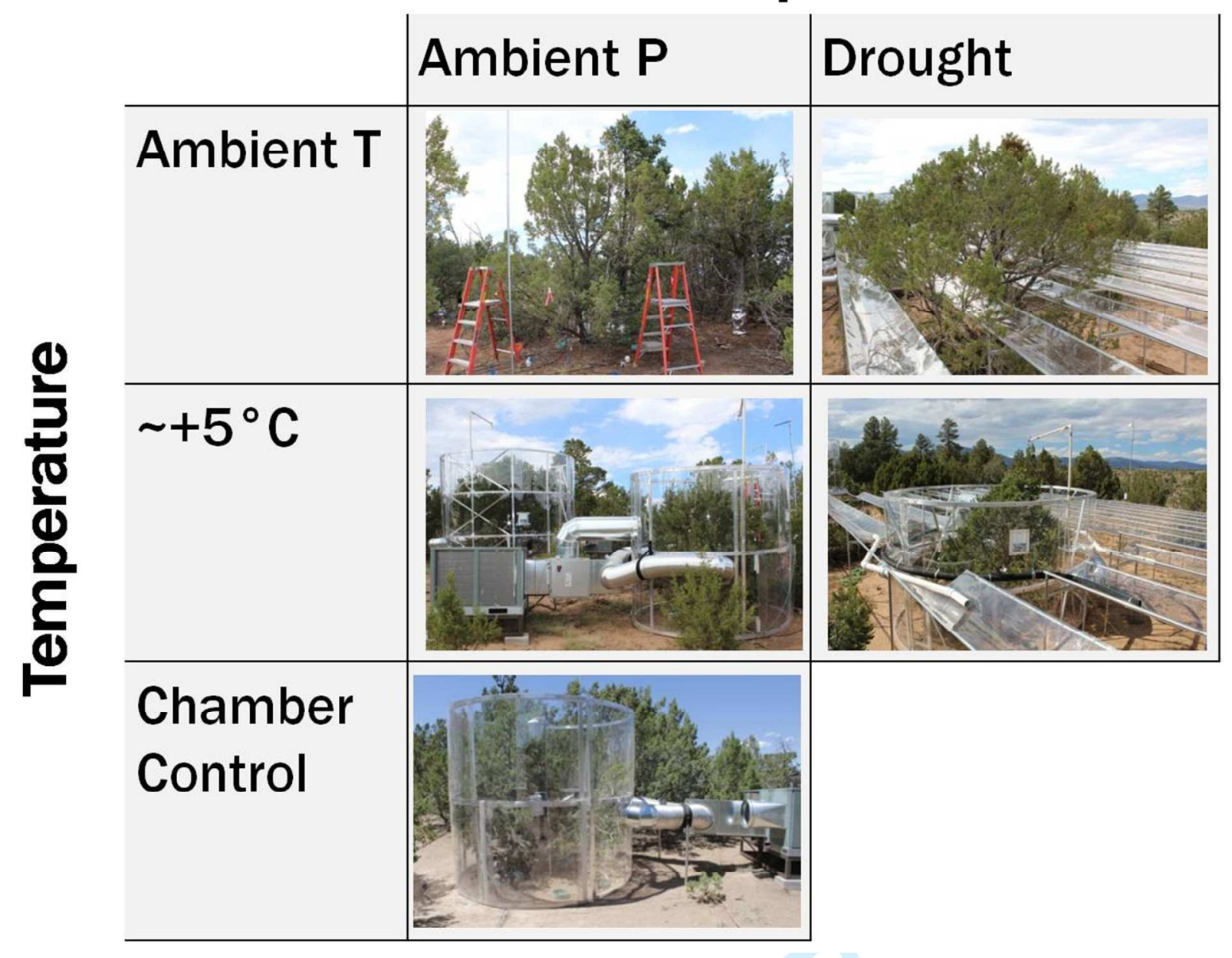

18 Fig S1. Design of the Los Alamos Survival-Mortality experiment (SUMO). Drought was

19 induced with a $\sim 45 \%$ throughfall rain-out structure and temperature was modified with

20 transparent plastic open-top chambers regulated by heating and cooling units. Precipitation and

21 temperature factors were combined to provide ambient, drought, heat, and drought + heat

22 treatments. A chamber control treatment was implemented with an additional set of open-top

23 chambers regulated to ambient field air temperature. 


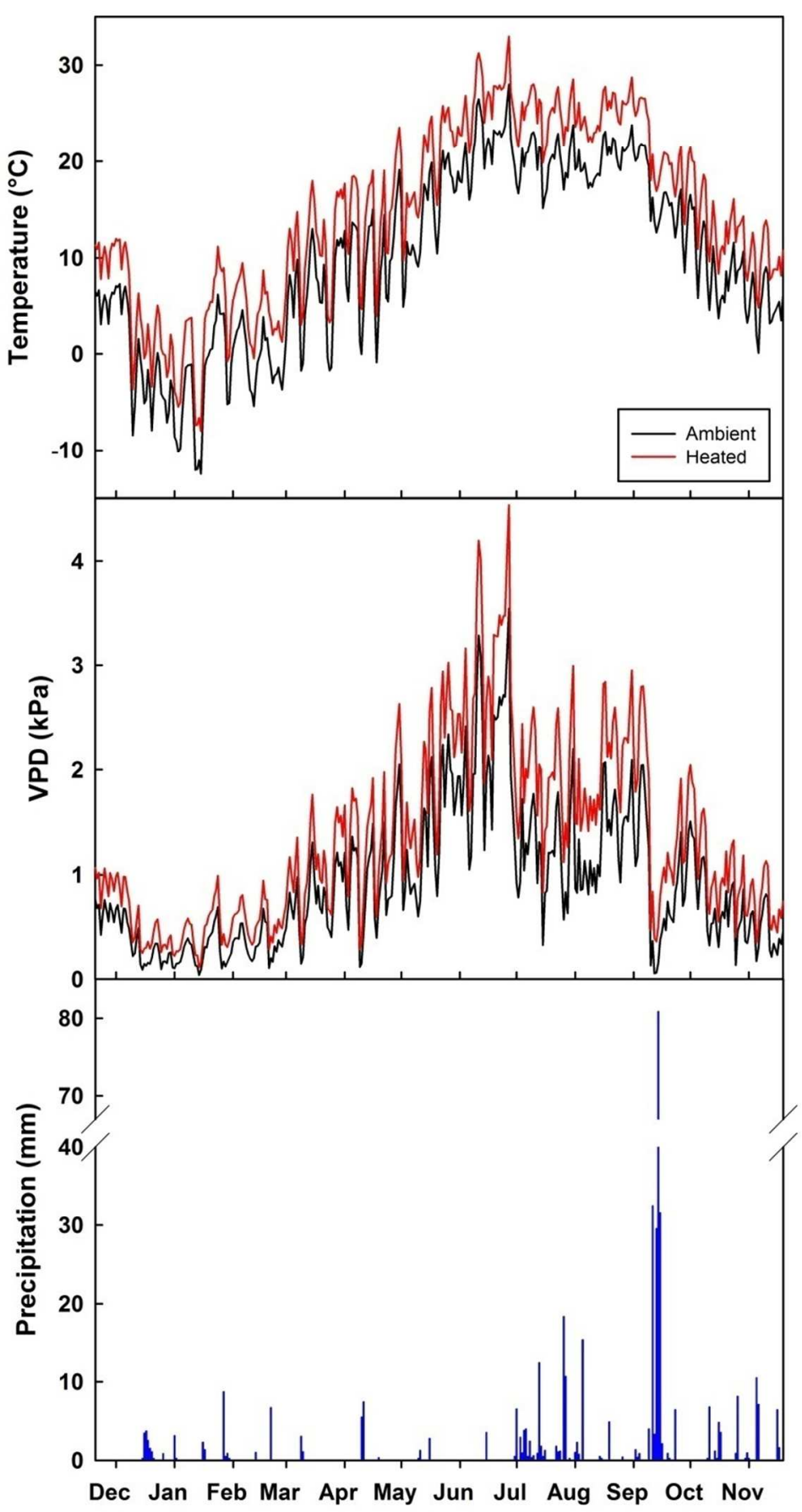

27 Fig S2. Mean daily temperature and vapor pressure deficit (VPD) for the ambient and heated

28 treatments (heat and drought+heat), and total daily precipitation at the SUMO experiment from

29 December 2012 to November 2013. 

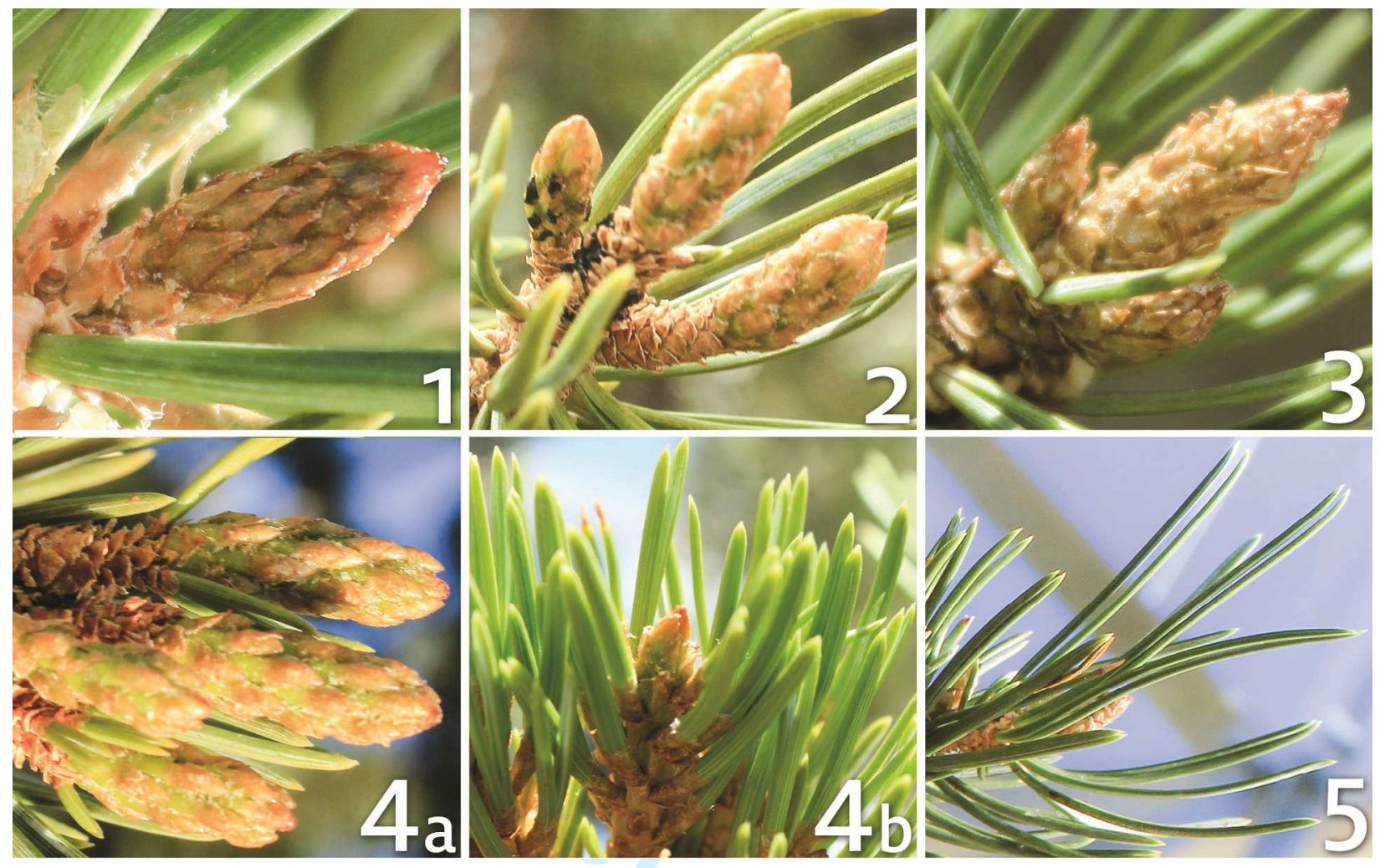

31 Fig S3. Phenological phases in our classification scheme for piñon pine: 1) bud dormant and

32 unchanged in size, 2) bud swelling or growth observed, 3) needle scales open (budbreak), 4) new

33 needle emergence and growth (both early (4a) and later (4b) examples of this stage are shown),

34 5) needle pairs separate. 


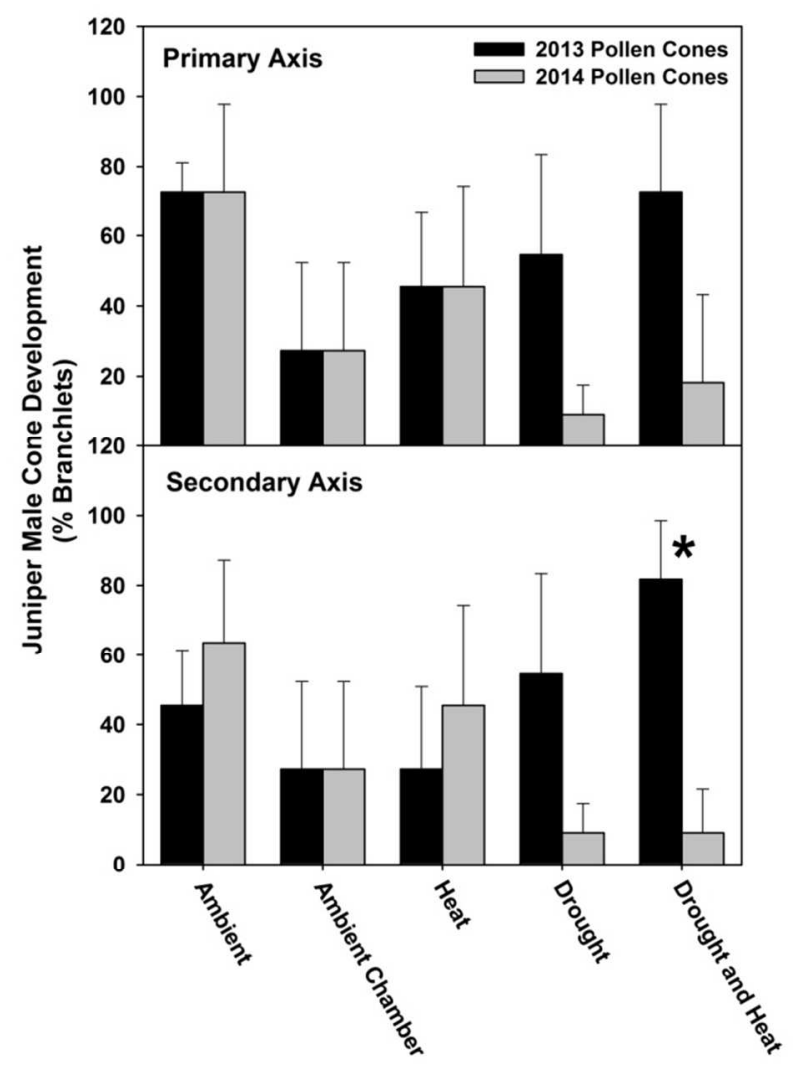

36 Fig S4. Pollen cone production in one-seed juniper by treatment. Pollen cones observed

37 releasing pollen in early 2013 and also those developed late in the growing season for 2014

38 pollen release are shown. Significant differences between 2013 and 2014 cones are noted with

39 an asterisk (Kruskal-Wallis test, $\mathrm{p}<0.05)$. Error bars are standard errors. 


\section{Supplemental Tables}

Table S1. Correlations are shown between pre-dawn shoot water potential (monthly and mean growing season) and shoot growth, needle growth, and needle emergence timing in primary and secondary axis branches of piñon pine. Only significant correlation coefficients are shown $(\mathrm{p}<0.05)$. The relationships between mean growing season water potential and shoot growth, growth, and needle emergence timing are also shown in Fig 5. There were no significant correlations for juniper between shoot growth and water potential.

\begin{tabular}{|c|c|c|c|c|c|c|c|c|c|c|}
\hline \multirow[b]{2}{*}{ Axis } & \multirow{2}{*}{$\begin{array}{l}\text { Phenology } \\
\text { Measurement }\end{array}$} & \multicolumn{9}{|c|}{ Correlation coefficient with water potential } \\
\hline & & March & April & May & June & July & August & Sept. & Oct. & Mean \\
\hline \multirow[t]{3}{*}{ Primary } & Shoot growth & 0.59 & & 0.70 & 0.49 & & 0.46 & & & 0.62 \\
\hline & Needle growth & 0.66 & & 0.66 & 0.48 & ( & 0.59 & & & 0.66 \\
\hline & Needle emergence & -0.61 & & -0.60 & & & -0.65 & & & -0.70 \\
\hline \multirow[t]{3}{*}{ Secondary } & Shoot growth & 0.73 & & 0.64 & 0.48 & & & 0.50 & & 0.71 \\
\hline & Needle growth & 0.79 & & 0.60 & 0.57 & & 0.60 & 0.45 & & 0.82 \\
\hline & Needle emergence & & & & & & & V & & -0.55 \\
\hline
\end{tabular}


Table S2. Correlations between June non-structural carbohydrate (NSC) concentrations and shoot growth, needle growth, and needle emergence timing in primary and secondary axis branches of piñon pine. Correlations are shown separately for NSC components of glucose and fructose (Gluc \& Fruc), sucrose, starch, and total NSC concentrations. Only significant correlation coefficients are shown $(\mathrm{p}<0.05)$. The relationships between shoot starch content and shoot growth, growth, and needle emergence timing are also shown in Fig 5. Significant correlations were found for juniper shoot growth in secondary axis branches with shoot glucose and fructose $(r=-$ $0.53, \mathrm{p}<0.05)$ and shoot total NSC $(\mathrm{r}=-0.46, \mathrm{p}<0.05$; data not show $)$.

\begin{tabular}{|c|c|c|c|c|c|c|c|}
\hline \multirow{2}{*}{ Tissue } & \multirow{2}{*}{$\begin{array}{l}\text { NSC } \\
\text { Component }\end{array}$} & \multicolumn{3}{|c|}{ Primary Axis } & \multicolumn{3}{|c|}{ Secondary Axis } \\
\hline & & $\begin{array}{l}\text { Shoot } \\
\text { growth }\end{array}$ & $\begin{array}{l}\text { Needle } \\
\text { growth }\end{array}$ & $\begin{array}{l}\text { Needle } \\
\text { emergence }\end{array}$ & $\begin{array}{l}\text { Shoot } \\
\text { growth }\end{array}$ & $\begin{array}{l}\text { Needle } \\
\text { growth }\end{array}$ & $\begin{array}{l}\text { Needle } \\
\text { emergence }\end{array}$ \\
\hline \multirow[t]{4}{*}{ Bole } & Gluc \& Fruc & & & & & & \\
\hline & Sucrose & & & 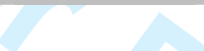 & & & \\
\hline & Starch & & & & & 0.54 & \\
\hline & Total NSC & & & & & & \\
\hline \multirow[t]{4}{*}{ Needle } & Gluc \& Fruc & & & & & & \\
\hline & Sucrose & & & & 2 & & \\
\hline & Starch & & & -0.45 & 0.51 & 0.55 & \\
\hline & Total NSC & & & & 0.47 & 0.46 & \\
\hline \multirow[t]{4}{*}{ Root } & Gluc \& Fruc & & & & & & \\
\hline & Sucrose & & & & & 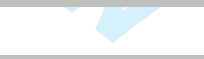 & 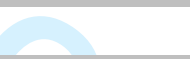 \\
\hline & Starch & & & & & & \\
\hline & Total NSC & & & & & & 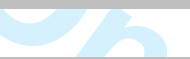 \\
\hline \multirow[t]{4}{*}{ Shoot } & Gluc \& Fruc & -0.48 & & & & & \\
\hline & Sucrose & & & & & 0.52 & \\
\hline & Starch & 0.49 & 0.55 & -0.65 & 0.62 & 0.77 & \\
\hline & Total NSC & & 0.51 & -0.57 & 0.58 & 0.77 & \\
\hline
\end{tabular}


Table S3. Correlations between pre-dawn shoot water potential (monthly and mean growing season) and June NSC and components in piñon pine. Only significant correlation coefficients are shown $(\mathrm{p}<0.05)$.

\begin{tabular}{|c|c|c|c|c|c|c|c|c|c|c|}
\hline & NSC & & & Correl & ion coet & ient wi & 1 water $p$ & ential & & \\
\hline Tissue & Component & March & April & May & June & July & August & Sept. & Oct. & Mean \\
\hline Bole & Gluc \& Fruc & & & & & & & & & \\
\hline & Sucrose & -0.51 & -0.68 & & & & & & & -0.52 \\
\hline & Starch & & & & & 0.55 & & & & \\
\hline & Total NSC & & -0.58 & & & & & & & \\
\hline Needle & Gluc \& Fruc & & & & & & & 0.47 & & \\
\hline & Sucrose & & & & & & & & & \\
\hline & Starch & 0.55 & & & & & & 0.44 & & 0.55 \\
\hline & Total NSC & & & 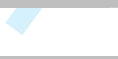 & $\gamma$ & & & 0.53 & & \\
\hline Root & Gluc \& Fruc & & & & & & & & & \\
\hline & Sucrose & & & & $\sqrt{x}$ & & & & & \\
\hline & Starch & & & & & 0.60 & 0.61 & & & 0.59 \\
\hline & Total NSC & & & & & 8 & & & & 0.58 \\
\hline Shoot & Gluc \& Fruc & & & -0.61 & -0.53 & & & & & \\
\hline & Sucrose & & & & & 8 & 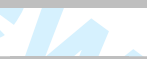 & & & \\
\hline & Starch & 0.50 & & & 0.67 & 0.58 & 0.49 & & & 0.70 \\
\hline & Total NSC & 0.49 & & & 0.54 & 0.56 & 0.45 & & & 0.63 \\
\hline
\end{tabular}

